\title{
Direct Determination of Glutathione $S$-transferase and Glucose-6-phosphate Dehydrogenase Activities in Cells Cultured in Microtitre Plates as Biomarkers for Oxidative Stress
}

\author{
Concepción García-Alfonso, ${ }^{1,2}$ Guillermo Repetto, ${ }^{1}$ Pilar Sanz, ${ }^{1}$ Manuel \\ Repetto $^{1}$ and Juan López-Barea ${ }^{2}$
}

${ }^{1}$ National Institute of Toxicology, P.O. Box 863, 41080 Seville, Spain; ${ }^{2}$ Departamento de Bioquímica y Biología Molecular, Universidad de Córdoba, Avda. de Medina Azahara s/n, 14071 Córdoba, Spain

\begin{abstract}
Summary - The enzymes glutathione $S$-transferase (GST) and glucose-6-phosphate dehydrogenase (G-6PDH) are implicated in the defence against oxidative stress. GST is mainly involved in the conjugation of electrophilic compounds with glutathione (GSH), although some of its isoenzymes display peroxidase activity. G-6PDH and glutathione reductase regenerate NADPH and GSH, respectively, to restore the reduced intracellular redox status following oxidative stress. Enzymatic assays for GST and G-6PDH were adäptèd and optimised to permit the direct in vitro determination of the effects of toxicants which induce oxidative stress in cells on microtitre plates, thereby avoiding the need to prepare cell-free extracts. To optimise the conditions of the enzymatic assays, GST activity was measured at substrate concentrations of 1-3mM GSH and 1-3mM 1-chloro-2,4-dinitrobenzene, while G-6PDH activity was measured at 7.5-37.5mM glucose-6-phosphate and 55-275mM NADP. Both enzymatic activities were directly proportional to cell number up to a density of $1 \times 10^{5}$ cells/well. The effects on GST and G-6PDH activities of three toxicants which induce oxidative stress - paraquat, iron (II) chloride and iron (III) chloride - were compared in cultured Vero cells to validate the new assays. Specific GST activity increased to $145 \%$ and $171 \%$ compared to the controls in cells treated with $5 \mathrm{mM}$ paraquat and $5 \mathrm{mM}$ iron (II) chloride, respectively, but was inhibited after exposure to $25 \mathrm{mM}$ iron (III) chloride. Specific G-6PDH activity increased to $136 \%$ compared to the control after exposure to $5 \mathrm{mM}$ paraquat, but was inhibited in cells exposed to $5 \mathrm{mM}$ iron (II) chloride and $25 \mathrm{mM}$ iron (III) chloride.
\end{abstract}

Key words: molecular biomarkers, oxidative stress, direct in vitro assay, glutathione $S$ transferase, glucose-6-phosphate dehydrogenase, Vero cells.

\section{Introduction}

Various environmental pollutants, such as metals, biphenyls and quinones, catalyse the conversion of oxygen to dangerous reactive oxygen species (ROS), such as the superoxide anion $\left(\mathrm{O}_{2} \cdot-\right)$, hydrogen peroxide $\left(\mathrm{H}_{2} \mathrm{O}_{2}\right)$ and the hydroxyl radical $\left(\mathrm{OH}^{\bullet}\right)$, which could damage nucleic acids, proteins, lipids and carbohydrates (1-3). All organisms are protected from ROS by antioxidant enzymes, such as superoxide 
dismutase, catalase and glutathione peroxidase, which cooperate to transform $\mathrm{O}_{2}{ }^{-}$and $\mathrm{H}_{2} \mathrm{O}_{2}$ to $\mathrm{H}_{2} \mathrm{O}$ and $\mathrm{O}_{2}$, avoiding the generation of harmful $\mathrm{OH}^{*}$, which is responsible for most oxidative stress $(1,3)$. This detoxification process results in increased concentrations of the oxidised forms of glutathione (GSSG) and pyridine nucleotide (NADP), while decreasing the pools of their reduced forms (GSH and NADPH) that provide physiological protection against the damaging effects of ROS (3). Two auxiliary enzymes, glutathione reductase (GOR) and glucose-6-phosphate (G-6P) dehydrogenase (G-6PDH), reduce GSSG and NADP to GSH and NADPH to maintain the intracellular redox status $(3,4)$. Some glutathione $S$-transferase (GST) isoenzymes display peroxidase activity with organic hydroperoxides as substrates (but not with $\mathrm{H}_{2} \mathrm{O}_{2} ; 3$, $5)$; thus GST is also implicated in the defence against oxidative stress (5). Oxidative stress results whenever antioxidant defences are overcome by pro-oxidant forces and ROS are not adequately removed (3). The activities of several antioxidative enzymes are modified under oxidative stress conditions induced by chemical pollutants and are used as biomarkers for oxidative stress in assessing environmental impact $(2,6,7)$. Our group has previously optimised the glutathione reductase assay in cultured cells, to permit a direct determination in the same microtitre plates in which the cells are grown (8).

The aim of the present study was to adapt the spectrophotometric assays used with soluble enzyme preparations for determination of G-6PDH (9) and GST (10) activities in order to permit the rapid, direct determination of enzyme activity in cells cultured on microtitre plates under various experimental conditions. The effects of the oxidative stress induced by three redox compounds, namely, paraquat, iron (II) chloride and iron (III) chloride, on GST and G-6PDH activities in cultured Vero cells were compared in order to validate the adapted assays.

\section{Materials and Methods}

\section{Toxicants and reagents}

Chemicals of the highest purity available were purchased from Sigma (St Louis, MO, USA) or Merck (Darmstadt, Germany).

\section{Cell culture}

The Vero cell line was originally established by T. Yasamura and Y. Kawakita (Chiba University, Japan) in 1962 from the kidney of a normal adult African green monkey (Cercopithecus aethiops), and has since been maintained and characterised by the American Type Culture Collection (Rockville, MD, USA; 11). The Vero cells used in this study were maintained as continuous monolayer cultures in Falcon flasks at $37^{\circ} \mathrm{C}$ in a humidified atmosphere containing $5 \% \mathrm{CO}_{2}: 95 \%$ air. Cells were grown in Dulbecco's modified Eagle's medium, supplemented with $10 \%$ fetal bovine serum, $100 \mathrm{IU} / \mathrm{ml}$ penicillin $\mathrm{G}$ and $100 \mathrm{mg} / \mathrm{ml}$ streptomycin (Flow Laboratories, Irvine, UK). The viability of plated cells was determined by trypan blue exclusion, and was higher than $90 \%$ in all the experiments.

\section{Toxicant exposure}

Cells were plated on 96-well tissue culture plates (Costar, Cambridge, MA, USA) at a density of 12,000 cells/well, and cultured as described above. After incubation for 24 hours, the culture medium was replaced with $0.2 \mathrm{ml}$ of fresh medium containing the toxicant to be tested, and the cells were incubated for a further 24 hours. The toxicants were dissolved in sterile water in concentrated form to dilute the culture medium by less than $1 \%$.

\section{Biochemical determinations and cytotoxicity assessment}

All determinations were carried out on the 96-well plates in which cell culture and exposure had taken place. The direct effects of the toxicants on the enzymatic activity were assessed in parallel. Absorbances were read on a Titertek Multiscan plate reader (Flow Laboratories, Helsinki, Finland).

Conjugation of GSH with 1-chloro-2,4dinitrobenzene (CDNB) was performed to permit GST activity to be assayed by measuring absorbance $(\Delta \mathrm{A})$ at $340 \mathrm{~nm}(10)$. The assay was carried out directly on 96-well microtitre culture plates, as follows. The culture medium was removed and the cells were washed twice with phosphate-buffered saline (PBS). The cells were then lysed by incubation with $100 \mu \mathrm{l} 1 \%$ Triton X-1000 for $45 \mathrm{~min}$ utes at $25^{\circ} \mathrm{C}$. The reagents for enzymatic activity were then added in a total volume of 
$100 \mu \mathrm{l}$ at concentrations double those required for the $200 \mu$ l final reaction mixtures, which contained $0.1 \mathrm{M}$ potassium phosphate buffer ( $\mathrm{pH}$ 6.5), 0.5mM EDTA, $0.1 \mathrm{mg} / \mathrm{ml}$ bovine serum albumin (BSA), and various substrate concentrations $(1-3 \mathrm{mM}$ GSH; $1-3 \mathrm{mM}$ CDNB). The change in absorbance was read between 5 and $10 \mathrm{~min}$ utes after addition of the reagents. The net activity was calculated by subtracting the non-enzymatic reaction of a blank without cells. The corrected change in absorbance was converted into specific enzymatic activity units by considering the GSH-CDNB extinction coefficient, volume and height of reaction mixture $(\mathrm{mm})$, time elapsed, and protein concentration of the sample. One unit of activity was defined as the amount of enzyme conjugating $1 \mu \mathrm{M}$ of $\mathrm{CDNB} /$ minute under the conditions described above.

G-6PDH activity was assayed directly on the 96-well microtitre culture plates, following NADPH formation (9) in the presence of $5 \mathrm{mM}$ glycyl buffer ( $\mathrm{pH} 7.5$ ), $7.5 \mathrm{mM} \mathrm{MgCl}_{2}$ and various concentrations of substrates (7.5-37.5 $\mu \mathrm{M}$ G-6P; 55-275 $\mathrm{M}$ NADP). The changes in absorbance at $340 \mathrm{~nm}$ were read between 0 and 10 minutes after the reaction started. The net activity was calculated by subtracting the non-enzymatic reaction of a blank without cells at each concentration of substrate tested.

Protein was determined in situ by adapting the Bradford method (12) to 96-well microtitre plates (13). Plates were washed twice with PBS, and twice with distilled water. Then $100 \mu \mathrm{M} 0.1 \mathrm{M} \mathrm{NaOH}$ was added to each well and the plates were incubated for 2 hours at $37^{\circ} \mathrm{C}$ to lyse the cells and dissolve the protein. Serial dilutions of BSA in $0.1 \mathrm{M} \mathrm{NaOH}$ were used as protein standards. Protein reagent (Bio-Rad Laboratories, Richmond, CA, USA) was added to each well, and absorbance was read at $620 \mathrm{~nm}$ after $30 \mathrm{~min}$ utes.

\section{Effects of cell number on glutathione}

S-transferase and glucose-6-phosphate dehydrogenase activities

The effects of cell density on GST and G-6PDH activities were determined with cells from continuous monolayer cultures after trypsinisation and serial dilution in PBS. Aliquots $(0.2 \mathrm{ml})$ of each cell dilution were added to the 96-well tissue culture plates (six wells/concentration). The plates were centrifuged at $880 \mathrm{~g}$ for 7 minutes in an appropriate rotor (Sigma, Osterode, Germany). Supernatant was gently aspirated with a multichannel pipette, and the intracellular activities were determined, as above.

\section{Statistical analysis}

All experiments were carried out three times, with six wells/assay. The statistical significance of the differences in enzymatic activities was determined by one-way analysis of variance (ANOVA; 14). When the data did not fulfil the requirements for the ANOVA test, a non-parametric method, the Mann-Whitney U-test, was used (15).

\section{Results}

\section{Optimisation of the glutathione S-transferase assay}

The standard spectrophotometric method for the GST assay in cell-free extracts, described by Habig et al. (10), was adapted for assessing the GST activity directly in cells grown on microtitre plates, to avoid the need to prepare a cell-free extract. Vero cells were plated $(12,000 /$ well), and GST activity was determined after incubation for 48 hours. The influence of substrate concentrations was initially compared. Figure 1 shows the time-course of GSH conjugation, at various concentrations of GSH and CDNB. The net GSH activities were quite similar at all substrate concentrations tested, i.e. 0.00875 $\Delta \mathrm{A} /$ minute in the presence of $1 \mathrm{mM} \mathrm{GSH}$ and $1 \mathrm{mM} \mathrm{CDNB}$, and $0.01075 \Delta \mathrm{A} /$ minute in the presence of $1.5 \mathrm{mM}$ GSH and $1.5 \mathrm{mM}$ CDNB. This indicates that even the lowest substrate concentrations used were saturating. By contrast, the absorbance increase observed for blank wells without cells, due to direct chemical reaction among substrates, was more significant with the higher substrate concentrations tested $(0.0013 \Delta \mathrm{A} /$ minute at $1.5 \mathrm{mM})$ than with the lower concentrations $(0.0007$ $\Delta \mathrm{A} /$ minute at $1 \mathrm{mM}$; Figure 1 ). This increase was even greater with the highest concentration of substrates tested ( $2 \mathrm{mM}$ and $3 \mathrm{mM}$; data not shown). Since the linearity of the assay also decreased with increased substrate concentrations, $1 \mathrm{mM} \mathrm{GSH}$ and $1 \mathrm{mM}$ CDNB were routinely selected as concentrations for the adapted GST assay. Since GST conjugation with CDNB was not linear for 
Figure 1: Time-course of change in absorbance after conjugation of glutathione (GSH) with 1-chloro-2,4-dinitrobenzene (CDNB) in Vero cells (GSH activity)

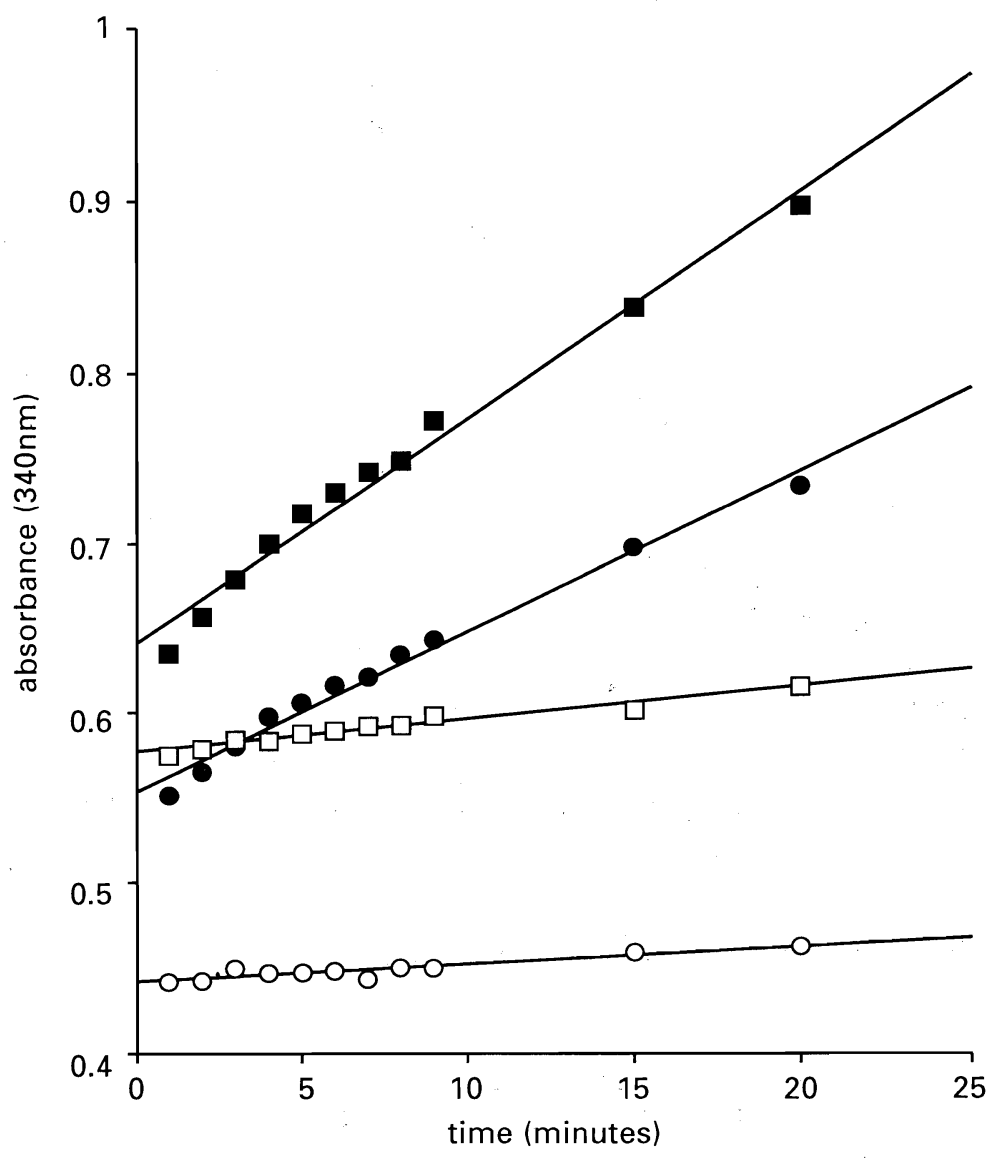

- = $1 \mathrm{mM}$ GSH and $1 \mathrm{mM}$ CDNB with cells $(r=0.9929) ; 0=1 \mathrm{mM}$ GSH and $1 \mathrm{mM} C D N B$ blank; $=1.5 \mathrm{mM} G S H$ and $1.5 \mathrm{mM}$ CDNB with cells $(r=0.9908) ; \square=1.5 \mathrm{mM}$ GSH and 1.5mM CDNB blank.

The results are the means of six experiments.

the first 5 minutes, GST activity was determined between 5 and 10 minutes, when there was good linearity $(r=0.9952)$.

Optimisation of the glucose-6-phosphate dehydrogenase

The standard spectrophotometric assay for $\mathrm{G}-6 \mathrm{PDH}$ in cell-free extracts (9) was also adapted for direct assessment in cells grown on 96-well microtitre plates. Figure 2 shows the time-course of NADPH formation in the presence of various concentrations of G-6P and NADP. While little enzymatic activity was observed with the concentrations used for the standard spectrophotometric assay (data not shown), the activity was greater with two-fold higher concentrations $(15 \mu \mathrm{M}$ 
Figure 2: Time-course of change in absorbance after formation of NADPH (glucose-6-phosphate dehydrogenase [G-6PDH] activity)

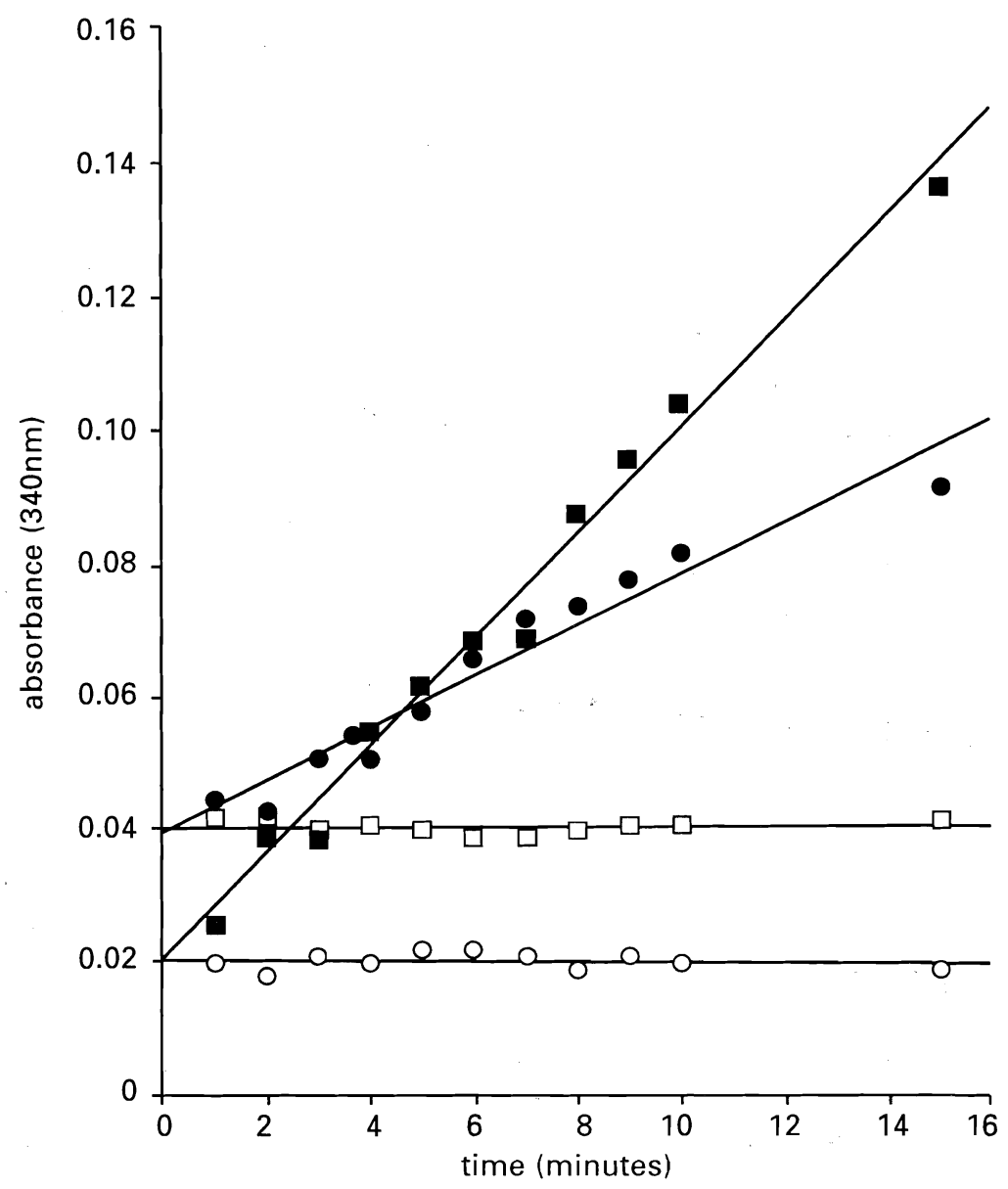

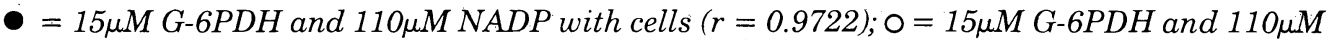
NADP blank; $=37.5 \mu M$ G-6PDH and $275 \mu M$ NADP with cells $(r=0.9927) ; \square=37.5 \mu M G$ $6 P D H$ and $275 \mu M$ NADP blank.

The results are the means of six experiments.

G-6P, $110 \mu \mathrm{M}$ NADP); and even greater with the five-fold higher concentrations $(37.5 \mu \mathrm{M}$ G-6P, $110 \mu \mathrm{M}$ NADP). With five-fold concentrations, reaction linearity was also better $(\mathrm{r}$ $=0.9927$ ) than that obtained with two-fold concentrations $(r=0.9722)$ for up to $15 \mathrm{~min}$ utes, and also had a higher net G-6PDH activity, i.e. $0.0078 \Delta \mathrm{A} /$ minute and 0.0037
$\Delta \mathrm{A} /$ minute, respectively. The direct chemical reaction of substrates in the blanks without cells was negligible. Consequently, $37.5 \mu \mathrm{M}$ G-6P and $275 \mu \mathrm{M}$ NADP were selected as substrate concentrations for the optimised method, and the absorbances were read between 5 and 10 minutes after the reaction had started. 
Figure 3: Effects of cell number in the glutathione $S$-transferase (GST) assay and the glucose-6-phosphate dehydrogenase (G-6PDH) assay

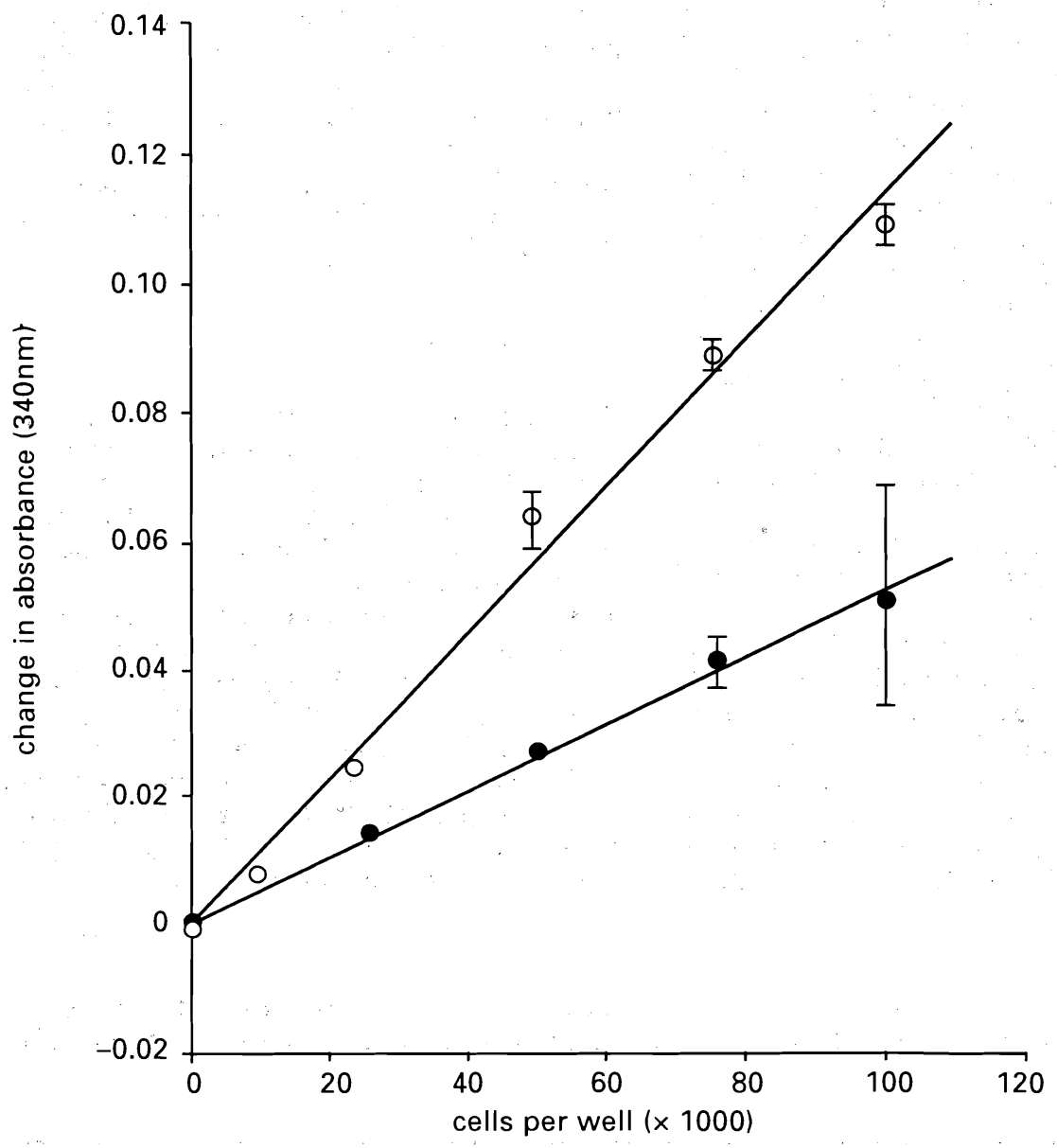

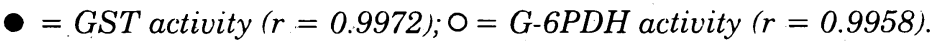

Each point is the mean $\pm S D$ of six experiments.

Effects of cell density in glutathione S-transferase and glucose-6-phosphate dehydrogenase activities

Figure 3 shows the straightforward relationships between GST activity or G-6PDH activity (total activity per well) and cell number. The activities of both enzymes were directly proportional to cell density up to $1 \times$ $10^{5}$ cells/well. This wide range includes the cells in each well due to proliferation after incubation for 48 hours (approximately 35,000 cells), but the assay could also be applied to cultures with more cell growth than this. 
Effects of compounds inducing oxidative stress in glutathione S-transferase and glucose-6-phosphate dehydrogenase

To validate the optimised assays under experimental conditions, the effects on GST and G-6PDH activities of three chemicals which induce oxidative stress (paraquat, iron [II] chloride and iron [III] chloride; 16, 17) were examined in Vero cells. Initially, experiments were carried out with a wide range of toxicant concentrations, and the inhibition of cell proliferation was evaluated by measuring the total protein content of the cultures $(12,13)$. Then, for each toxicant, one concentration near that causing a 50\% reduction in cell proliferation (EC50) was selected ( $5 \mathrm{mM}$ for paraquat [18]; $5.5 \mathrm{mM}$ for iron [II] chloride; $22 \mathrm{mM}$ for iron [III] chloride [19]), to detect changes in GST and G-6PDH activities in cells healthy enough to respond to the chemical insult. Such a sensitive marker of toxicity was used to avoid the need for more-specific viability endpoints related to cell metabolism.

GST and G-6PDH activities in untreated Vero cells were compared with those of cells exposed to $5 \mathrm{mM}$ paraquat, $5 \mathrm{mM}$ iron (II) chloride or $25 \mathrm{mM}$ iron (III) chloride. Other concentrations were also tested to compare the toxic effects of these compounds on these two activities (Table I). Compared to the untreated controls, the GST-specific enzymatic activity increased to $145 \%$ in cells exposed to $5 \mathrm{mM}$ paraquat, $171 \%$ in cells exposed to $5 \mathrm{mM}$ iron (II) chloride, and $415 \%$ in cells exposed to $7.5 \mathrm{mM}$ iron (III) chloride, while $25 \mathrm{mM}$, and especially $7.5 \mathrm{mM}$ iron (III) chloride caused a $72 \%$ inhibition of GST activity. When compared to the controls, G-6PDH activity increased to $136 \%$ in cells treated with $5 \mathrm{mM}$ paraquat, while $5 \mathrm{mM}$, and especially $7.5 \mathrm{mM}$ iron (II) chloride and $25 \mathrm{mM}$ iron (III) chloride led to a dramatic decrease in activity. Nevertheless, G-6PDH activity increased to $153 \%$ of control values in cells treated with $5 \mathrm{mM}$ iron (III) chloride.

\section{Discussion}

GOR and G-6PDH are implicated in cellular defences against oxidative stress, to restore the GSSG and NADPH levels that protect cells against the damaging effects of ROS (4). GSTs are mainly involved in the conjugation of electrophilic xenobiotics with GSH, although some of their isoenzymes also metabolise organic hydroperoxides and participate in antioxidative defence mechanisms $(3,5)$. In the present study, we assessed the use of the direct determination of GST and G$6 \mathrm{PDH}$ activities in cells cultured on microtitre plates as possible biomarkers of oxidative stress induced by chemicals, thereby avoiding the need to prepare cell-free extracts.

Table I: Effects of oxidative stress-inducing compounds on glutathione $S$-transferase (GST) and glucose-6-phosphate dehydrogenase (G-6PDH) activities

\section{Chemical (concentration)}

GST activity

(mU/mg protein)

G-6PDH activity

( $\mathrm{mU} / \mathrm{mg}$ protein)
(\%)

$\begin{array}{rlr}626 & \pm 5 & 100 \\ 852 & \pm 69^{* * *} & 136 \\ 495 & \pm 31 & 79 \\ 0 & \pm 0 * * * & 0 \\ 958 & \pm 87^{* * *} & 153 \\ 175 & \pm 31^{* * *} & 28\end{array}$

None

Paraquat (5mM)

Iron (II) chloride (5mM)

Iron (II) chloride ( $7.5 \mathrm{mM}$ )

Iron (III) chloride (5mM)

Iron (III) chloride (25mM)

$\begin{array}{rlr}314 & \pm 10 & 100 \\ 456 & \pm 22^{* * *} & 145 \\ 537 & \pm 40^{* * *} & 171 \\ 1034 & \pm 113^{* * *} & 415 \\ 299 & \pm 19 & 95 \\ 88 & \pm 25^{* * *} & 28\end{array}$

(\%)

Cells were cultured for 24 hours and then exposed for an additional 24 hours, as indicated.

$* * * p<0.001$. 
The effects on GST and G-6PDH activities of several substrate concentrations and different cell densities were initially studied to optimise the corresponding assays. When a fixed number of cells were assayed at different concentrations of GSH and CDNB, a time-dependent conjugation of both substrates was observed under all conditions tested. The increase of the non-enzymatic GSH conjugation and the need to avoid substrate inhibition led to the selection of $1 \mathrm{mM}$ GSH and 1mM CDNB for the routine GST assay, in agreement with the conditions previously described for the standard spectrophotometric assay (10). This was due to the fact that the net activity after blank correction was similar (but somewhat greater at higher concentrations), and that the linearity of the GST time-course at high substrate concentrations was lower. By contrast, when the G-6PDH activity of a fixed number of cells was assayed at different substrate concentrations, diverse slopes of time-dependent NADPH formation were observed. The activity was minimal with the lower substrate concentrations tested, but showed a better slope and linearity at higher concentrations. As the direct chemical reaction of substrates was not significant in any instance, $37.5 \mu \mathrm{M}$ G-6P and $275 \mu \mathrm{M}$ NADP were selected as substrate concentrations for routine assays, i.e. five times more concentrated than those in the standard spectrophotometric assay (9). Under the conditions previously described, the optimised GST and G-6PDH assays were directly proportional to the number of Vero cells per well, supporting the validity of this approach for assays with cultured cells.

The toxic effects of three chemicals known to induce oxidative stress $(16,17)$ were analysed as a practical application of the optimised GST and G-6PDH assays in Vero monkey kidney cells cultured on microtitre plates. Paraquat ' $\left(1,1^{\prime}\right.$-dimethyl-4,4' bipyridilium dichloride) is a highly toxic herbicide (18); the bipyridyl ring of which accepts one electron from NADPH, being reduced to the corresponding monocation radical. This derivative subsequently reduces $\mathrm{O}_{2}$ to deleterious ROS, while being reoxidised to its dication form in a "redox cycling" process which promotes oxidative stress (16, 20 ). Similarly, free (non-protein-bound) iron dramatically enhances oxidative stress, by catalaysing conversion of $\mathrm{H}_{2} \mathrm{O}_{2}$ into highly toxic hydroxyl radicals by the Fenton reaction. In this process, iron (II) interacts with $\mathrm{H}_{2} \mathrm{O}_{2}$, which yields a hydroxyl ion and a hydroxyl radical, while iron (II) is oxidised to iron (III). Subsequently, superoxide anion reduces iron (III) to its primitive ferrous state, iron (II), which reinitiates the reaction $(17,21,22)$.

Oxidative conditions alter the intracellular redox status by oxidising the pools of NADPH/NADP and GSH/GSSG (23, 24). This is counteracted by increased G-6PDH and GOR activities mediated by the high NADP and GSSG concentrations existing under such circumstances (25-28). The stimulation of GST and G-6PDH produced by $5 \mathrm{mM}$ paraquat was similar to that previously reported for superoxide dismutase (18), but significantly less marked than that produced on GOR (8). GST activity was stimulated four-fold, to a similar extent as GOR (8) by $7.5 \mathrm{mM}$ iron (II) chloride, while G-6PDH was fully inhibited. However, the effects of $5 \mathrm{mM}$ iron (II) chloride (the concentration closest to the EC50) were not so marked, with GST increasing by $171 \%$, and G-6PDH decreasing to $79 \%$ of the control values. GST was not affected by $5 \mathrm{mM}$ iron (III) chloride, while G-6PDH increased 1.5-fold over control cells, by contrast with the near-50\% inhibition of GOR at the same concentration of this toxicant (8).

The increased GST activity caused by paraquat and iron (II) chloride is in agreement with the peroxidase activity of some GST isoenzymes, which break down $\mathrm{H}_{2} \mathrm{O}_{2}$ generated under oxidative conditions caused by environmental pollutants. The stimulation of G-6PDH activity after exposure to paraquat also seems to be a defensive response to restore the reduced form of NADP which diminishes under oxidative stress. The inhibitory effects of high iron (III) chloride concentrations on both enzymatic activities could be due to different availabilities of both iron forms (19), leading to different levels of toxicity. The increase of these antioxidative activities observed in cells exposed to $5 \mathrm{mM}$ paraquat, $7.5 \mathrm{mM}$ iron (II) chloride or $5 \mathrm{mM}$ iron (III) chloride, could be due to short-term or long-term effects. Short-term effects could be attributed to the activation of the enzymes in response to the oxidised intracellular redox state (26-28). The long-term effects could be due to enhanced expression of the gene encoding for 
antioxidative enzymes, as previously reported in bacteria for catalase, alkylhydroperoxide reductase, endonuclease IV, G-6PDH and manganese-superoxide dismutase under oxidative stress (29-30). However, this possibility requires further investigation.

In conclusion, the GST and G-6PDH assays can be directly applied to cells grown on microtitre plates, thereby avoiding the time-consuming and cumbersome preparation of cell-free extracts. The changes in GST and G-6PDH activities detected in Vero cells exposed to three toxicants (paraquat, iron [II] chloride and iron [III] chloride), confirms that this simple and rapid assay is suitable for the routine in vitro screening of toxicants capable of inducing oxidative stress.

\section{Acknowledgements}

Dr García-Alfonso received fellowships from the Consejería de Educación y Ciencia, Junta de Andalucía, and Universidad de Córdoba, for her stay in the Instituto Nacional de Toxicología, Seville, Spain. The authors thank S. Jiménez and M. Gutiérrez for their technical assistance. This work was supported by grants to Juan López-Barea from DGICYT (PB95-0557-C02-02) and Junta de Andalucía (Group CVI 0151).

Received 6.1.98; accepted for publication 24.3.98.

\section{References}

1. Sies, H. (1988). Oxidative stress: quinone redox cycling. ISI Atlas of Science: Biochemistry 1, 109-114:

2. Winston, G.W. \& Di Giulio, R.T. (1991). Pro-oxidant and antioxidant mechanisms in aquatic organisms. Aquatic Toxicology 19, 137-161.

3. Sies, H. (1986). Biochemistry of oxidative stress. Angewandte Chemie - International Edition in English 25, 1058-1071.

4. Liochev, S-I. \& Fridovich, I. (1991). Effects of overproduction of superoxide dismutase on the toxicity of paraquat toward Escherichia coli Journal of Biological Chemistry 266, 8747-8750.

5. Jacoby, W.B. (1985). Glutathione transferases: an overview. Methods in Enzymology 113, 495-499.

6. Livingstone, D.R. (1991). Towards a specific index of impact by organic pollution for marine invertebrates. Comparative Biochemistry and Physiology - C Pharmacology Toxicology and Endocrinology 100, 151-155.

7. Rodríguez-Ariza, A., Peinado, J., Pueyo, C. \& López-Barea, J. (1993). Biochemical indicators of oxidative stress in fish from polluted littoral areas. Canadian Journal of Fisheries and Aquatic Sciences 50, 2568-2573.

8. García-Alfonso, C., Sanz, P., Repetto, G., Repetto, M. \& López-Barea, J. (1995). Direct determination of glutathione reductase in cells cultured in microtitre plates as a biomarker for oxidative stress. ATLA 23, 531-538.

9. Kornberg, A. \& Horecker, B.L. (1955). Glucose-6phosphate dehydrogenase: enzymes of carbohydrate metabolism. Methods in Enzymology 1, 323-327.

10. Habig, W.H., Pabst, M.J. \& Jacoby, W.B. (1974). Glutathione $S$-transferases: the first enzymatic step in mercapturic acid formation. Journal of Biological Chemistry 249, 7130-7139.

11. Hann, W.D. \& Rhim, J.S. (1974). Vero (Kidney, African Green Monkey, Cercopithecus aethiops). In Flow Manual, pp. 4-45. Irvine, UK: Flow Laboratories Ltd.

12. Bradford, M. (1976). A rapid and sensitive method for the quantification of microgram quantities of protein utilising the principle of protein-dye binding. Analytical Biochemistry 72, 248-254.

13. Repetto, G. \& Sanz, P. (1993). Neutral red uptake, cellular growth and lysosomal function: in vitro effects of 24 metals. ATLA 21, 501-507.

14. Sokal, R.R. \& Rohlf, F.J. (1969). Biometry, 832pp. New York: Freeman \& Co.

15. Siegel, S. (1956). Nonparametric Statistics for the Behavioral Sciences, 258pp. New York: McGrawHill.

16. Minakata, K., Suzuki, O., Saito, S-I. \& Harada, N. (1993). Ascorbate radical levels in human sera and rat plasma intoxicated with paraquat and diquat. Archives of Toxicology 67, 126-130.

17. Miller, D.M., Grover, T.A., Nayini, N. \& Aust, S.D. (1993). Xantine oxidase- and iron-dependent lipid peroxidation. Archives of Biochemistry and Biophysics 301, 1-7.

18. García-Alfonso, C., López-Barea, J., Sanz, P., Repetto, G. \& Repetto, M. (1995): Stimulation of antioxidative enzymes by paraquat in cultured Vero cells. Veterinary and Human Toxicology 37, 414-421.

19. García-Alfonso, C., López-Barea, J., Sanz, P., Repetto, G. \& Repetto, M. (1996). Changes in antioxidative activities induced by $\mathrm{Fe}$ (II) and $\mathrm{Fe}$ (III) in cultured Vero cells. Archives of Environmental Contamination and Toxicology $\mathbf{3 0}$ 431-436.

20. Bus, J.S., Aust, S.D. \& Gibson, J.E. (1977). Lipid peroxidation as a proposed mechanism for paraquat toxicity. In Biochemical Mechanisms of Paraquat Toxicity (ed. A.P. Autor), pp. 157-174. London: Academic Press.

21. Halliwell, B. \& Gutteridge, J.M.C. (1991). Role of free radicals and catalytic metal ions in human disease: an overview. Methods in Enzymology 186, 1-85.

22. Zager, R.A., Schimpf, B.A., Bredl, C.R. \& Gmur, D.J. (1993). Inorganic iron effects on in vitro hypoxic proximal renal tubular cell injury.'Journal of Clinical Investigation 91, 702-708.

23. Brigelius, R. (1985). Mixed disulfides: biological functions and increases in oxidative stress. In Oxidative Stress (ed. H. Sies), pp. 243-272. London: Academic Press.

24. Masanet, J., Gómez-Lechón, M.J. \& Castell, J.V. 
(1988). Hepatic toxicity of paraquat in primary cultures of rat hepatocytes. Toxicology in Vitro $\mathbf{2}$, 275-282.

25. López-Barea, J., Bárcena, J.A., Bocanegrá, J.A., Florindo, J., García-Alfonso, C., López-Ruíz, A., Martínez-Galisteo, E. \& Peinado, J. (1990). Structure, mechanism, functions and regulatory properties of glutathione reductase. In Glutathione: Metabolism and Physiological Functions (ed. J. Vin̄a), pp. 105-116. Boca Raton, FL, USA: CRC Press.

26. Llobell, A., López-Ruíz, A., Peinado, J. \& LópezBarea, J. (1988). Glutathione reductase directly mediates the stimulation of yeast glucose-6-phosphate dehydrogenase by GSSG. Biochemical Journal 249, 293-296.

27. Peinado, J., Florindo, J. \& López-Barea, J. (1992).
Glutathione reductase from Saccharomyces cerevisiae undergoes redox interconversion in situ and in vivo. Molecular and Cellular Biochemistry 110, 135-143.

28. García-Alfonso, C., Martínez-Galisteo, E., Llobell, A., Bárcena, J.A. \& López-Barea, J. (1993). Regulation of horse liver glutathione reductase. International Journal of Biochemistry $\mathbf{2 5}$, 513-520.

29. Tartaglia, L.A., Storz, G., Farr, S.B. \& Ames, B.N. (1991). The bacterial adaptation to hydrogen peroxide stress. In Oxidative Stress: Oxidants and Antioxidants (ed. H. Sies), pp. 155-169. London: Academic Press.

30. Demple, B. (1991). Regulation of bacterial oxidative stress genes. Annual Review of Genetics 25, 315-337. 